\title{
Research on Distributed Energy Operation Model of Distribution Network in China
}

\author{
Li Qiang $^{1 *}$, Xing Yahong ${ }^{1}$, Gu Zhihong ${ }^{1}$, Liu ZhiWei ${ }^{1}$, Qi HuiWen ${ }^{1}$, Liu Zhuo ${ }^{1}$ \\ ${ }^{1}$ Economic and Electrical Research Institute of Shanxi Electrical Power Company of SGCC, Taiyuan, Shanxi ZIP code 030000, China
}

\begin{abstract}
With the development of China's social economy, the total demand for energy is increasing. Compared with traditional thermal power plants, natural gas distributed energy stations have many advantages, which can realize the cascade utilization of energy, the efficiency of energy utilization can be improved. Using natural gas as fuel, $\mathrm{SO}_{2}$ and dust pollution can be eliminated, and improve the safety and reliability of power supply. However, the distributed energy station needs more capital investment during the project construction, but the distributed energy station has difficulty financing. Firstly, this paper introduces the environment of distributed energy policy in China, analyzes the current status of the China's natural gas distributed energy. Then, this paper summarizes the development of the Germany the energy industry project financing, and provides experience for the use of the financing methods of China's energy stations. Finally, the model of China's natural gas energy construction is introduced from three aspects of investment, financing and engineering construction. The research results of this paper can provide experience for the project financing of the distributed energy station in China.
\end{abstract}

\section{Introduction}

With the support of policies, China's natural gas distributed energy industry has developed rapidly, but the proportion is still small, the development model is relatively simple, most of them are demonstration projects. The combination of distributed energy and renewable energy is beneficial to the utilization of renewable energy, and can reduce the pollution of the environment and emission reduction of the society [1]. In the context of the transformation of China's energy structure, distributed energy plays an important role in promoting energy structure improvement. The development of distributed energy in China is in its initial stage. Compared with the developed countries, the investment market mechanism is lacking [2].

In the research of distributed energy investment model, Alarcon Rodriguez A (2009) focused on the uncertainty of renewable energy. Based on the portfolio theory, and the factors that affect the distributed generation are analyzed quantitatively [3]. Carpinelli G (2013) analyzed the investment optimization problem of distributed energy with uncertain factors [4]. Pedrasa M A A (2010) proposed that distributed energy is an important way of low carbon development, and combined with carbon market to put forward the design principle of investment model on China Distributed Energy, and the different investment strategies that considered the changes of policy and technology are applied [5]. Huang Jiayi (2008) studied the characteristics of new energy investment, and put forward the risk prevention measures in the investment [6]. Driesen J (2008) based on the characteristics of
China's energy production, put forward the relationship between energy consumption and environmental protection [7]. The current research on the comprehensive benefits of distributed energy system is lacking. Some scholars use multi-attribute evaluation theory to analyze the comprehensive benefits of distributed systems [8].

In the research of distributed energy efficiency analysis, Akorede M F(2010) analyzed the cost and benefit of the building according to the life cycle theory, and put forward the evaluation principles and calculation methods of building energy consumption [9]. Ren H (2010) analyzed the necessity of cost-benefit analysis and evaluation of distributed energy projects under low carbon targets with MILP modell [10]. Yazdani D(2008) summarized distributed Energy Nonlinear adaptive Synchronization Grid-Connected Technique[11]. Chamam A (2010) and Wang X (2010) analyzed distributed energy optimization for Target Tracking in Wireless Sensor Networks [12][13]. Alarcon Rodriguez A (2009) designed mufti-objective planning framework for stochastic and controllable distributed energy resources [14]. Contreras J (2001) set up simulation and evaluation modell to optimize distributed Energy management systems [15]. Zhang L (2014) optimized the energy operation of micro-grid distributed energy system, and proposed a comprehensive benefit evaluation modell from the aspect of social investment [16]. Saha AK(2009) analyzed the investment characteristics of distributed energy and the uncertain factors affecting energy industry, and puts forward the countermeasures [17]. Maribu K M (2007) studied the mechanism of distributed energy market, in terms of policies and regulations, and promoted its de-

\footnotetext{
*Corresponding author's e-mail: 2858877150@qq.com
} 
velopment by improving the market mechanism and policy mechanism [18].

The above literature shows that in the study of distributed energy project financing, different financing modells should be selected according to project capacity. Due to the lack of research on project financing in China, there is no perfect market mechanism and regulations, therefore, the natural gas distributed energy station project operation model is taken as research object in paper. The rest of the paper is organized as follows. Section 2 introduces the natural gas distributed energy policy environment and the status of the China natural gas distributed energy station project. Section 3 designs the investment, financing and engineering model of China's natural gas distributed energy station project. Section 4 highlights the main conclusions of this paper.

\section{Development status of natural gas distributed energy}

\subsection{Analysis of policy environment}

(1) National distributed energy support policy

China's natural gas distributed energy started in 2002. In 2011, the state issued the "guidance on the development of natural gas distributed energy ", as natural gas distributed energy was supported by policy, the project came into research and demonstration. Table 1 is national level distributed energy policy.

Table 1 National level distributed energy policy.

\begin{tabular}{|c|c|c|c|}
\hline $\begin{array}{c}\text { Serial } \\
\text { number }\end{array}$ & Time & Department & Policy name \\
\hline 1 & 2011 & The National Energy Administration & 《guidance on the development of natural gas distributed energy $》$ \\
\hline 2 & 2012 & $\begin{array}{l}\text { National Development and Reform } \\
\text { Commission }\end{array}$ & 《Natural gas utilization policy》 \\
\hline 3 & 2012 & The finance ministry. & $\begin{array}{l}\text { 《Opinions on accelerating the development of green building in } \\
\text { China》 }\end{array}$ \\
\hline 4 & 2013 & National Power Grid Corp & 《Opinion on grid connected service of distributed power》 \\
\hline 5 & 2013 & $\begin{array}{l}\text { National Development and Reform } \\
\text { Commission }\end{array}$ & 《Distributed generation management scheme》 \\
\hline 6 & 2013 & The State Council & 《Action plan for the prevention and control of air pollution》 \\
\hline 7 & 2014 & $\begin{array}{l}\text { National Development and Reform } \\
\text { Commission }\end{array}$ & $\begin{array}{l}\begin{array}{l}\text { Implementation details of a demonstration project of natural gas } \\
\text { distributed energy }\end{array}\end{array}$ \\
\hline 8 & 2014 & $\begin{array}{l}\text { National Development and Reform } \\
\text { Commission }\end{array}$ & 《Regulating the price of power generation by natural gas》 \\
\hline 9 & 2014 & $\begin{array}{l}\text { National Development and Reform } \\
\text { Commission }\end{array}$ & $\begin{array}{l}\begin{array}{l}\text { UGuiding opinions on accelerating the construction of gas storage } \\
\text { facilities } 》\end{array}\end{array}$ \\
\hline
\end{tabular}

(2) Local distributed energy support policy

In 2014, China promulgated the implementation rules for the demonstration project of distributed natural gas resources. In 2015, the power system reform proposed a comprehensive release of the user side distributed power market, China's provinces actively carried out the pilot project of distributed energy, and table 2 is the local distributed energy support policy.

Table 2 the local distributed energy support policy

\begin{tabular}{|c|c|c|c|}
\hline $\begin{array}{c}\text { Serial } \\
\text { number }\end{array}$ & Time & Province & Policy name \\
\hline 1 & 2008 & Shanghai & $\begin{array}{c}\text { 《Special support measures for distributed energy supply system and gas air } \\
\text { conditioning development in Shanghai } 》\end{array}$ \\
\hline 2 & 2013 & Beijing & 《Opinions on the implementation of natural gas distributed energy system》 \\
\hline 3 & 2013 & Shijiazhuang & $\begin{array}{c}\begin{array}{l}\text { 《Interim management measures of distributed energy supply system for public } \\
\text { buildings in Shijiazhuang》 }\end{array}\end{array}$ \\
\hline 4 & 2014 & Changsha & $\begin{array}{c}\begin{array}{l}\text { 《Interim Measures for promoting the development of natural gas distributed } \\
\text { energy in Changsha》 }\end{array}\end{array}$ \\
\hline 5 & 2012 & Chongqing & $\begin{array}{l}\text { 《Research on distributed energy generation planning in Chongqing } \\
\qquad(2012 \sim 2017)\rangle\end{array}$ \\
\hline 6 & 2012 & Shanxi & 《Development plan of natural gas distributed energy in Shaanxi $》$ \\
\hline 7 & 2014 & Guangzhou & $\begin{array}{c}\text { 《Development plan of Guangzhou heat and power cogeneration and distributed } \\
\text { energy station》 }\end{array}$ \\
\hline
\end{tabular}


(3) The policy of natural gas market

In 2015, China's nonresident natural gas price dropped by about $30 \%$, and its long-term goal was the marketization of natural gas industry. Table 3 was the policy of natural gas marketization.

Table 3 the natural gas marketization policy

\begin{tabular}{|c|c|c|c|}
\hline $\begin{array}{c}\text { Serial } \\
\text { number }\end{array}$ & Time & Department & Policy name \\
\hline 1 & 2008 & Shanghai & 《Natural gas utilization policy in Shanghai 》 \\
\hline 2 & 2013 & Beijing & 《Notice on the reform of nonresident gas prices》 \\
\hline 3 & 2012 & Chongqing & 《Regulatory measures for oil and gas pipeline facilities $》$ \\
\hline 4 & 2012 & Shanxi & 《Construction and operation management of natural gas infrastructure $》$ \\
\hline 5 & 2014 & Guangzhou & 《Opinions on establishing the ladder price system of residents' gas》 \\
\hline 6 & 2014 & $\begin{array}{l}\text { National Development and } \\
\text { Reform Commission }\end{array}$ & $\begin{array}{l}\begin{array}{l}\text { Notifications of regulating the management of natural gas power genera- } \\
\text { tion electricity price } 》\end{array}\end{array}$ \\
\hline
\end{tabular}

The marketization policy standardizes the natural gas power generation industry to adapt to the marketoriented reform of natural gas. The above policies have improved the economy of natural gas distributed energy and promoted the development of natural gas distributed energy. Although many policies has been introduced, but in the technical standards, financial and tax financial policies still need to be refined.

\subsection{Situation of distributed energy development}

The installed capacity of China's natural gas distributed energy project is $3.8 \mathrm{GW}$. China's natural gas distributed energy projects are mainly in Beijing, Shanghai, Guangzhou and other cities. The typical regional distributed energy system is the Guangzhou University city project. The building distributed energy system includes the Shanghai Pudong International Airport energy center and the Huangpu District Central Hospital of Shanghai. By 2014, 82 projects of natural gas distributed energy have been built. Table 4 is the distributed energy capacity of China's natural gas.

Table 4 China's natural gas distributed energy capacity

\begin{tabular}{ccccccc}
\hline Capacity & & \multicolumn{5}{c}{ Completed } \\
(MW) & 2010 & 2011 & 2012 & 2013 & 2014 & Being built \\
Below 10MW & 16 & 6 & 24 & 58 & 29 & 248 \\
10-30MW & 0 & 0 & 0 & 0 & 0 & 58 \\
30-100 MW & 300 & 0 & 0 & 390 & 246 & 861 \\
Total capacity & 316 & 6 & 24 & 448 & 275 & 1167 \\
\hline
\end{tabular}

(1) Building distributed energy project

China is in the stage of urbanization construction. In order to adjust the economic structure, a number of industrial development zones are being built. These industrial development zones have diversified energy demand. Because the distributed energy of natural gas can provide power supply, heating, cooling and other energy forms for the users, it has the advantages of energy saving, environmental protection and high efficiency. Therefore, the Industrial Development Zone has a large demand for the distributed energy of natural gas. As the natural gas distributed energy installed capacity is $0.15 \mathrm{GW}$. Table 5 is the distribution of China's building natural gas distribution projects.

Table 5 The distribution of China's building natural gas distribution projects.

\begin{tabular}{cc}
\hline Province & Proportion \\
\hline Beijing & $30 \%$ \\
Shanghai & $21 \%$ \\
Guangdong & $11 \%$ \\
\hline
\end{tabular}

\begin{tabular}{cc}
\hline Jiangsu & $8 \%$ \\
Hunan & $7 \%$ \\
Others & $23 \%$ \\
\hline
\end{tabular}

(2) Distributed energy system for regional natural gas The new industrial development zone is located in the suburbs of the city and is easy to plan. Natural gas distributed energy system can be used as a means of load regulation, and can also be used as a city's power supply under special circumstances. Table 6 is the distribution of regional natural gas distribution projects in China.

Table 6 The distribution of regional natural gas distribution projects in China.

\begin{tabular}{cc}
\hline Province & Proportion \\
\hline Guangdong & $30 \%$ \\
Chongqing & $26 \%$ \\
Tianjin & $14 \%$ \\
Guangxi & $13 \%$ \\
Beijing & $10 \%$ \\
Others & $7 \%$ \\
\hline
\end{tabular}




\section{The construction model of natural gas distributed energy}

The thermoelectric cooling system is an important way for the efficient utilization of natural gas, which is a typical distributed energy structure, the integrated energy utilization efficiency is more than $70 \%$. With the aid of the distributed energy CHP system and the auxiliary power of renewable energy, the energy supply system is managed intelligently, so as to coordinate the energy demand of electricity, heating and cooling in the region.

\subsection{Natural gas distributed energy investment model}

\subsubsection{PPP investment model}
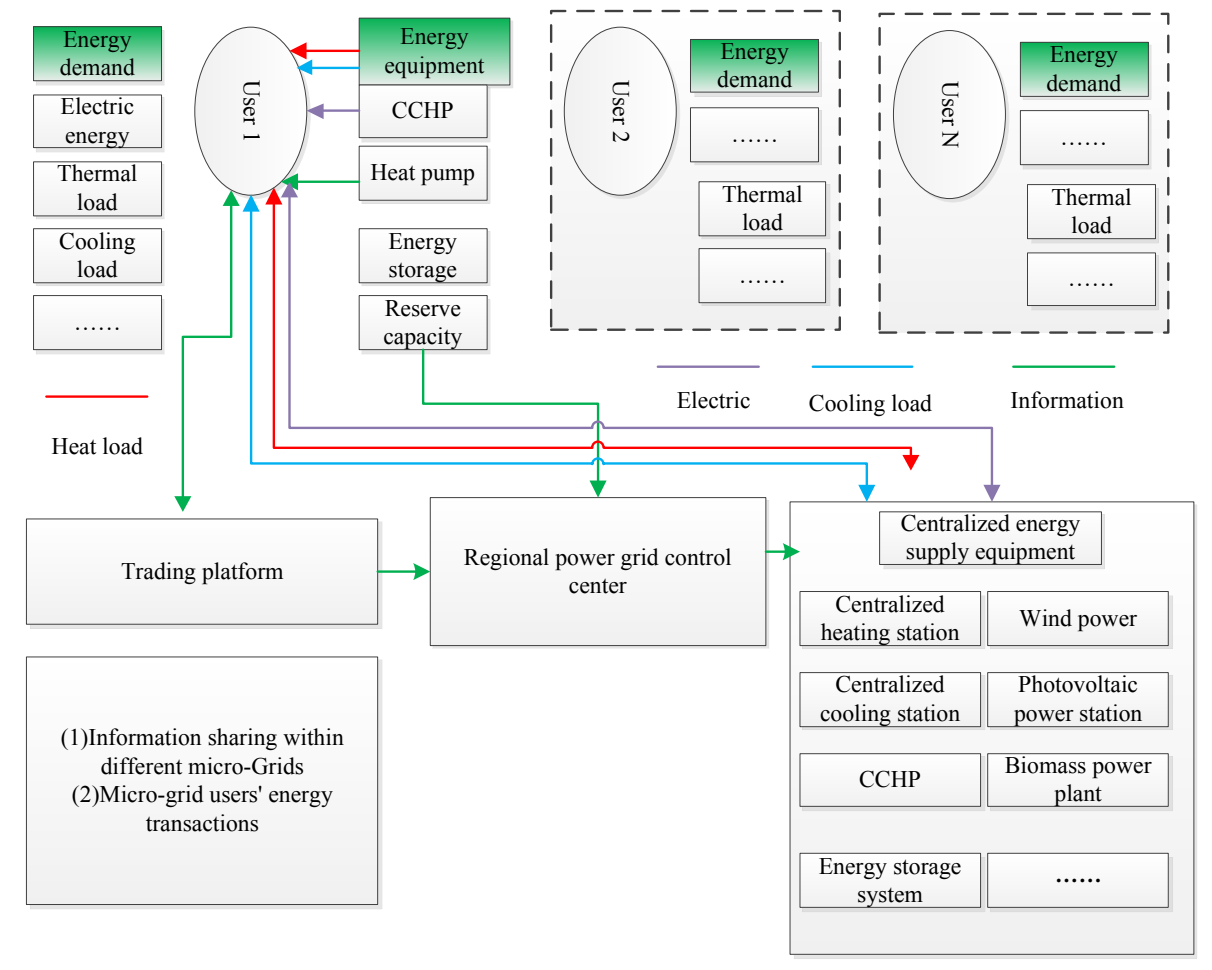
frastructure construction cooperation between government and private enterprises. This model, the government and investors determines the feasibility of the project, can short project feasibility study cycle and save the cost of the government investment. In the process of building distributed energy stations, the government can reduce the risk of investors and project contractors, and reduce the difficulty of project financing. Multi parties jointly build a distributed energy station project, which can introduce advanced technology and management to improve the quality of project construction and operation. The government has a certain control over the project of distributed energy power station, and establishes alliance with many stakeholders, harmonize the interests of all parties, and reduce the risk of distributed energy station operation. Figure 1 is a typical micro grid distributed energy structure.

Figure 1 Typical micro grid distributed energy structure

\subsubsection{BOT+CO investment model}

The construction of distributed energy in BOT model is taken as an example. It takes energy management as the core, and its main service is operation management, en- ergy services and so on. The cloud center can provide operational data analysis, financial support services, smart energy services and evaluation services. The distributed energy BOT $+\mathrm{CO}$ construction model is shown in Figure 2. 


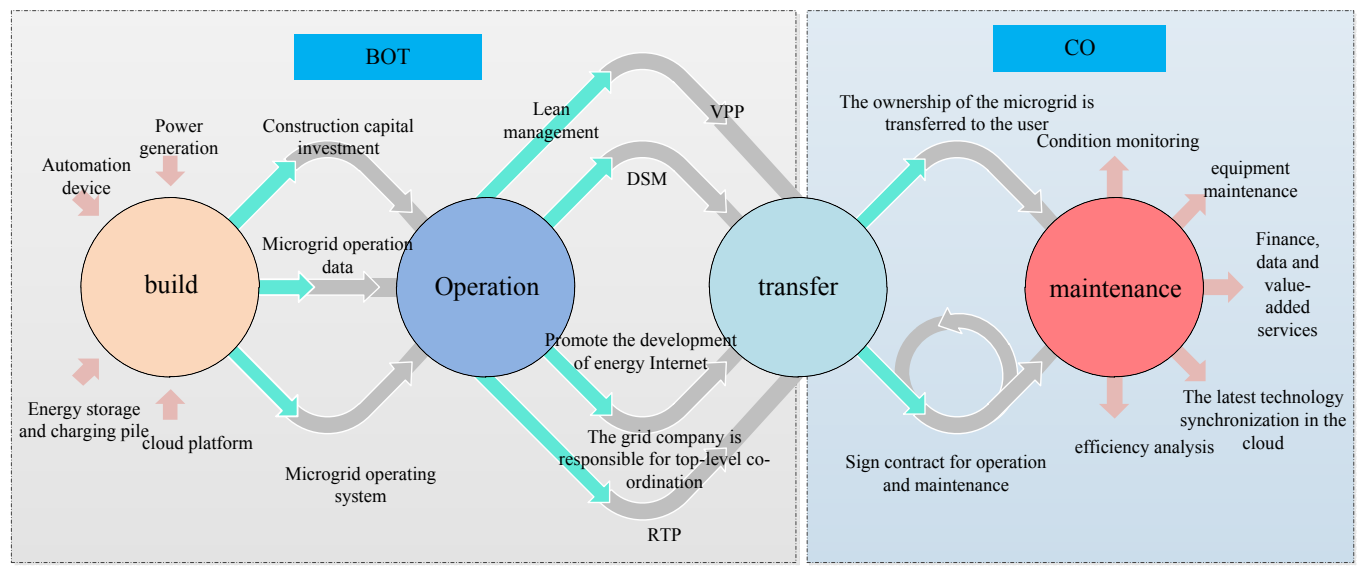

Figure 2 The distributed energy BOT $+\mathrm{CO}$ construction model

\subsubsection{Other investment models}

\section{(1)BOOT model}

In this investment model, the distributed energy investor has ownership of energy center facilities and is responsible for operation and management. After the expiration of the project contract, the investor can transfer the energy center to the user, or grant the Energy Service Companies to operate the energy center. This model is suitable for the region distributed energy projects. Table 7 summarizes the characteristics of regional distributed energy projects:

Table 7 The characteristics of regional distributed energy projects

\begin{tabular}{cc}
\hline Investment modell & To Establish company, owner-self construction or joint venture \\
\hline Grid-connected model & Grid connected, insufficient electric load is provided by the power grid \\
Load characteristics & Electric load, steam demand, heating load and cooling load \\
System equipment composition & Internal-combustion engine, heat recovery steam generator, new energy \\
and conventional energy \\
Tse of land
\end{tabular}

(2) PFI model

In this model, operators can set up company to invest in building distributed energy. The user and the Energy Service Companies jointly build the energy center. The company is responsible for the construction project management and the operation. Table 8 summarizes the characteristics of building and regional distributed energy projects:

Table 8 The characteristics of building and regional distributed energy

\begin{tabular}{cc}
\hline Investment model & To Establish company, owner-self construction \\
\hline Grid-connected model & Grid connected \\
Load characteristics & Load demand diversity \\
System equipment composition & Gas internal combustion engine, heat recovery steam \\
Use of land & generator, new energy and conventional energy \\
To buy land or To rent land
\end{tabular}

(3) Energy management contract

Energy management contract is a market-oriented operation energy saving mechanism to reduce energy costs. The Energy Service Companies has signed energy management contracts with distributed energy users, and provided users with energy saving scheme design, fi- nancing, construction and other services. This investment model is suitable for building outdated and obsolete project facilities and equipment. Table 9 summarizes the characteristics of the building type distributed energy sources:

Table 9 The characteristics of building distributed energy

\begin{tabular}{cc}
\hline Investment model & Contract energy management, owner-self construction or joint venture \\
\hline Grid-connected model & Grid connected, insufficient electric load is provided by the power grid \\
Load characteristics & Electric load, cooling load, heating load and hot water load \\
System equipment composition & Gas internal combustion engine, Bromine refrigerator, new energy and \\
conventional energy \\
Use of land
\end{tabular}$\quad$\begin{tabular}{c} 
The owner provides land \\
\hline
\end{tabular}


3.1.4 Comparison and analysis of different investment models
For different types of distributed energy users, different operation models should be adopted. Table 10 introduces the characteristics of different distributed energy projects energy consumption.

Table 10 Characteristics of energy use for distributed energy projects

\begin{tabular}{|c|c|c|c|c|c|}
\hline Type & $\begin{array}{c}\text { Comprehensive Indus- } \\
\text { trial Park } \\
\end{array}$ & Data center & Commercial buildings & $\begin{array}{c}\text { Airport and rail- } \\
\text { way station }\end{array}$ & Hospital \\
\hline Ownership & $\begin{array}{l}\text { Management Commit- } \\
\text { tee / heating company }\end{array}$ & $\begin{array}{l}\text { Telecom } \\
\text { operators }\end{array}$ & Developers & $\begin{array}{c}\text { Civil aviation and } \\
\text { Railway Bureau }\end{array}$ & Hospital \\
\hline $\begin{array}{l}\text { Characteristics } \\
\text { of energy use }\end{array}$ & $\begin{array}{l}\text { The steam load is stable } \\
\text { throughout the year, } \\
\text { and the heating load } \\
\text { fluctuates with the sea- } \\
\text { sons. }\end{array}$ & $\begin{array}{l}\text { Cooling load } \\
\text { is stable } \\
\text { throughout } \\
\text { the year }\end{array}$ & $\begin{array}{l}\text { The hot water load is } \\
\text { stable throughout the } \\
\text { year, and the cooling } \\
\text { load fluctuates with the } \\
\text { seasons. }\end{array}$ & $\begin{array}{l}\text { Heating load and } \\
\text { the cooling load } \\
\text { fluctuates with the } \\
\text { seasons. }\end{array}$ & $\begin{array}{l}\text { The steam and heat } \\
\text { load are stable } \\
\text { throughout the } \\
\text { year, and the cool- } \\
\text { ing load fluctuates } \\
\text { with the seasons. }\end{array}$ \\
\hline Project type & $\begin{array}{c}\text { Regional distributed } \\
\text { energy }\end{array}$ & $\begin{array}{l}\text { Building } \\
\text { distributed } \\
\text { energy }\end{array}$ & $\begin{array}{c}\text { Building distributed } \\
\text { energy }\end{array}$ & $\begin{array}{l}\text { Building distribut- } \\
\text { ed energy }\end{array}$ & $\begin{array}{l}\text { Building distribut- } \\
\text { ed energy }\end{array}$ \\
\hline
\end{tabular}

A reasonable investment model can save investment in energy equipment. Table 10 summarizes the operating characteristics of different investment models:

Table 11 Adaptability of different investment models

\begin{tabular}{ccccc}
\hline $\begin{array}{c}\text { Source of } \\
\text { funds } \\
\begin{array}{c}\text { Construction } \\
\text { unit }\end{array}\end{array}$ & BT model & BOT model & PFI model & EPC model \\
\cline { 2 - 6 } & Bank, the private enterprise & Private financing funds & Owner \\
$\begin{array}{c}\text { Project man- } \\
\text { agement right }\end{array}$ & $\begin{array}{c}\text { governmental } \\
\text { agencies }\end{array}$ & $\begin{array}{c}\text { The right of management belongs to } \\
\text { the project investor and is returned } \\
\text { to the government after the expira- } \\
\text { tion period. }\end{array}$ & $\begin{array}{c}\text { The right of management belongs to } \\
\text { the project investor and is returned } \\
\text { to the government after the expira- } \\
\text { tion period. }\end{array}$ & $\begin{array}{c}\text { The project } \\
\text { investor }\end{array}$ \\
$\begin{array}{c}\text { Application } \\
\text { scope }\end{array}$ & $\begin{array}{c}\text { Nonprofit in- } \\
\text { frastructure }\end{array}$ & Big profitability infrastructure & Profitability infrastructure & $\begin{array}{c}\text { Large in- } \\
\text { dustrial } \\
\text { project }\end{array}$ \\
\hline
\end{tabular}

The BOOT model is suitable for new distributed energy center project, the BOT model is suitable for the construction of the municipal facilities energy center, which are dominated by the government. The PFI model is suitable for the transformation of distributed energy centers. The EMC model is suitable for central heating and cooling projects with serious energy waste or equipment aging.

\subsection{Natural gas distributed energy financing model}

Financing plays a vital role in the development of natural gas distributed energy. Figure 3 introduces the policy financing model and market financing model of distributed energy construction. 


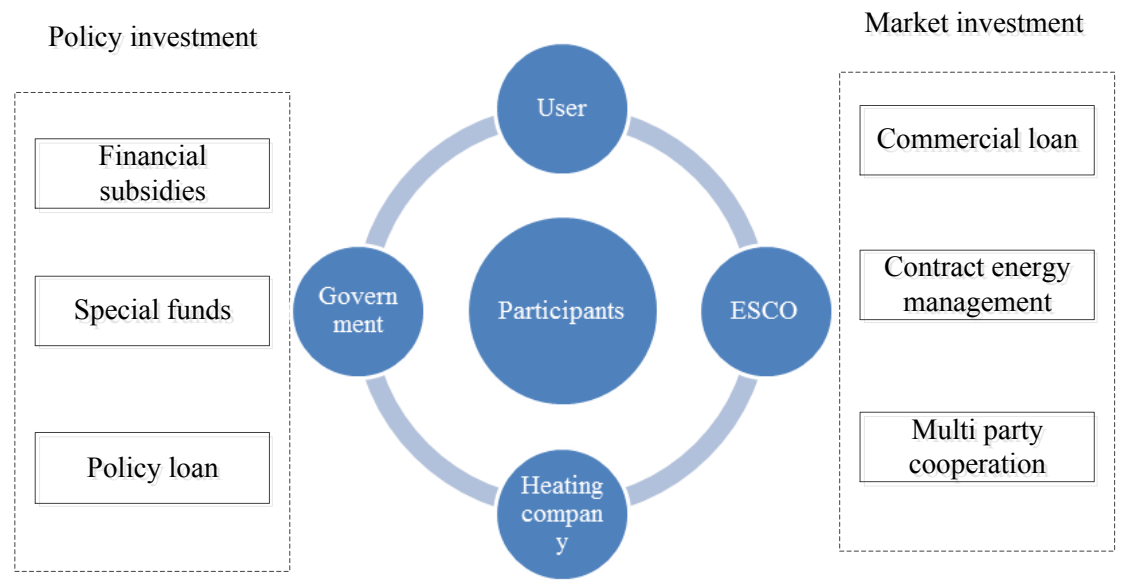

Figure 3 Distributed energy financing model

\subsubsection{Analysis of the financing model in Germany}

The development of Germany new energy is fast. This paper summarizes Germany financing methods in the field of distributed energy.

(1) Commercial bank model

The development of renewable energy industry in Germany is rapid. The German financial system is dominated by banks. Distributed energy enterprises are mainly small and medium-sized enterprises, its financing is difficult. Since 2000, Commerzbank has set up a business unit to invest in new energy projects.

(2) Direct investment model of equipment manufacturers

Large manufacturing enterprises in Germany have a high market share. Such as Enercon is a famous German wind turbine manufacturer and has many power stations in Germany, and participating in the investment of distributed energy generation projects can get loans from banks, and can also form their own industrial chains.

(3) Financing model under government guarantee

Kreditanstalt Fur Wiederaufbau is a bank that provides long-term credit for the small and medium enterprises. In the examination and approval project, the commercial model is adopted to ensure the supervision and management of the project process. Most small and medium-sized enterprises can get start-up funds under policy guarantee.

(4) International capital, social capital and private capital financing.

Because of the superior investment environment, the folk capital and social capital in the distributed energy industry are very active in Germany, and the folk capital plays an important role in the development of the distributed energy industry. Considering international capital financing, the overseas capital market will not emphasize the profit of the renewable energy enterprises before the market, but focus on the growth of the enterprises. Therefore, many potential new energy enterprises can obtain fund in the capital market.

\subsubsection{The financing model of China's distributed energy project}

(1) Government secured financing model

There are two main models of government secured financing: direct financing, guiding investors into the distributed energy industry, giving investors preferential policies and regulations; indirect financing, providing security for distributed energy enterprises and providing low interest loans. In this model, the government acts as an intermediary, the enterprise applies for loans to the bank, the government carries on the examination to the enterprise, if it conforms to the industrial policy, then agrees to guarantee.

(2) National debt project

The national debt project belongs to government, it adapts to large-scale distributed energy projects. Because the Chinese government issues limited national debt, it cannot be widely applied. It is mainly applicable to projects with low commercialization and policy support. Because China's state-owned enterprises have good credit records, they are easy to obtain policy loans and commercial loans. Therefore, the project approval can be quickly obtained.

\subsubsection{Innovative financing model}

Learning from the four innovative financing models in Germany, which can achieve the goal of China's distributed energy development, and increase the financing channels with low cost and encourage high-quality projects. Most of the new financing ways pay more attention to efficiency and profitability. For example, the distributed energy projects set up revenue companies to raise funds; the financing of large-scale projects can be funded by the institutional financing model; the lease model is suitable for small distributed energy transformation projects; and the public raising and community fund-raising are applicable to smaller distributed energy projects. Figure 4 introduces four innovative financing models. 


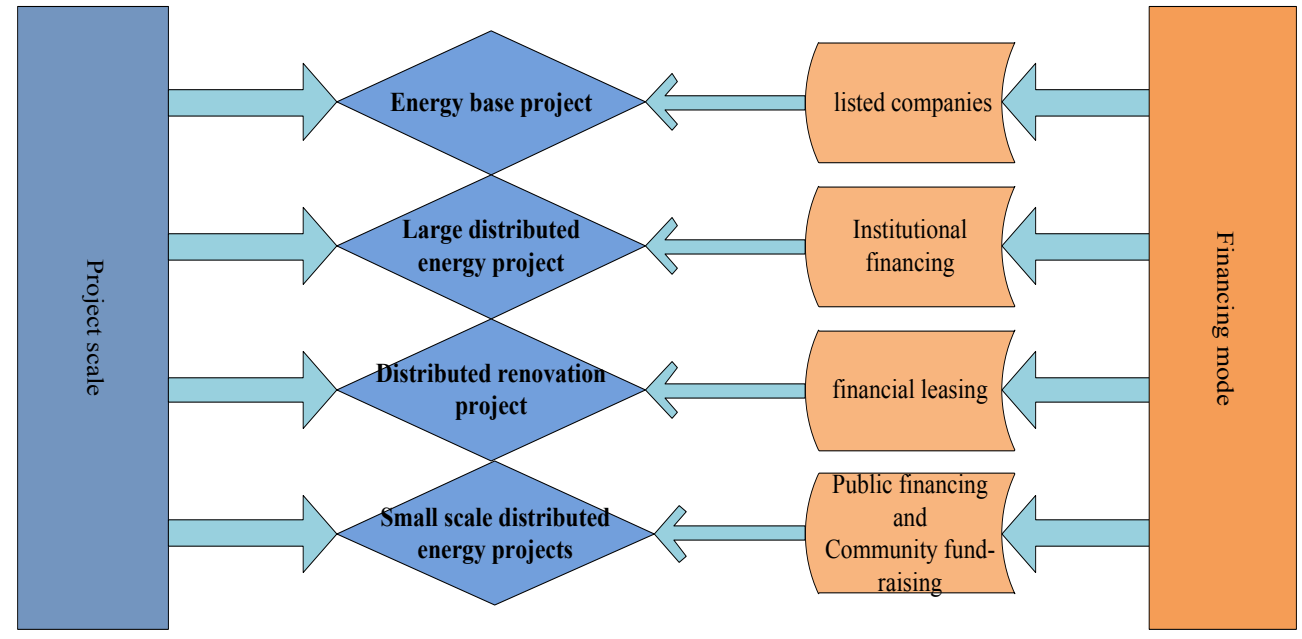

Figure 4 Four innovative financing models for distributed energy

In the specialized service of the financing institutions, the financial institutions set up special financing department for small projects, simplify the financing service process to improve the efficiency; in the innovation of financial products, the financial institutions innovate a variety of forms of long-term loans and small loans, and provide the creation of green credit and the pledge of the right of income. New financial products can explore the model of public financing, and encourage social capital investment on the distributed energy. For the local government, it is suggested to establish a cooperative platform for the distributed energy investment and financing. The government set up a public guarantee to eliminate the risk of repayment.

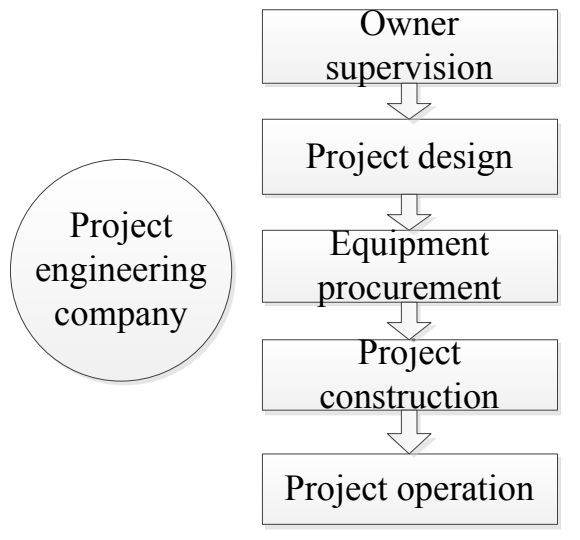

\subsection{Natural gas distributed energy engineering model}

(1) EPC model of distributed energy power station EPC (Engineering Procurement Construction) is an integrated model of design, procurement and construction. After the decision of the distributed energy project owner, the owner entrusts the engineering company with a general contract for the design, procurement and construction of the project. In the EPC model, the project mainly manages and controls the progress, cost, quality and safety of the project. The EPC specific model structure is shown in Figure 5.

Figure 5 Distributed energy EPC construction model

For EPC model, the owner has the overall management and monitoring of the distributed energy project. The general contractor has the right to operate, and strengthens the coordination of various departments. The general contractor is responsible for the cost, duration and safety quality of the distributed energy project.
(2) PMC model of distributed energy power station PMC (Project Management Consultant) is the project management contract. The project contractor represents the owner on the comprehensive management of the distributed energy station. The PMC specific pattern structure is shown in Figure 6. 


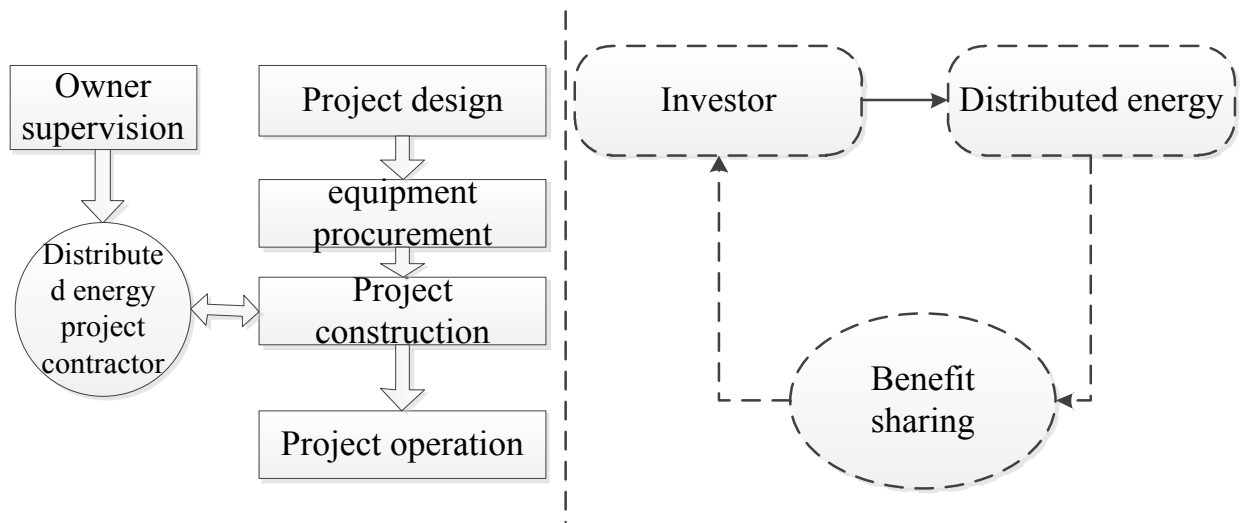

Figure 6 Distributed energy PMC construction model

The PMC model is applicable to the project with large investment costs. Because the investors grant the project construction to the distributed energy Project Company with high efficiency and management experience, the contractor coordinates management of distributed energy projects, and reduces the contradiction between design and project construction. By optimizing the design of distributed energy project, it can save the cost of project investment and shorten the project time period.

(3) DB model of distributed energy power station
DB (Design and Build) is the design - construction model. This model selects highly qualified companies to complete the construction of distributed energy projects. The DB model avoids the contradiction between the design and construction of the distributed energy project, reduces the cost of the project and selects the high quality distributed energy construction plan according to evaluation method. The DB specific pattern structure is shown in Figure 7.

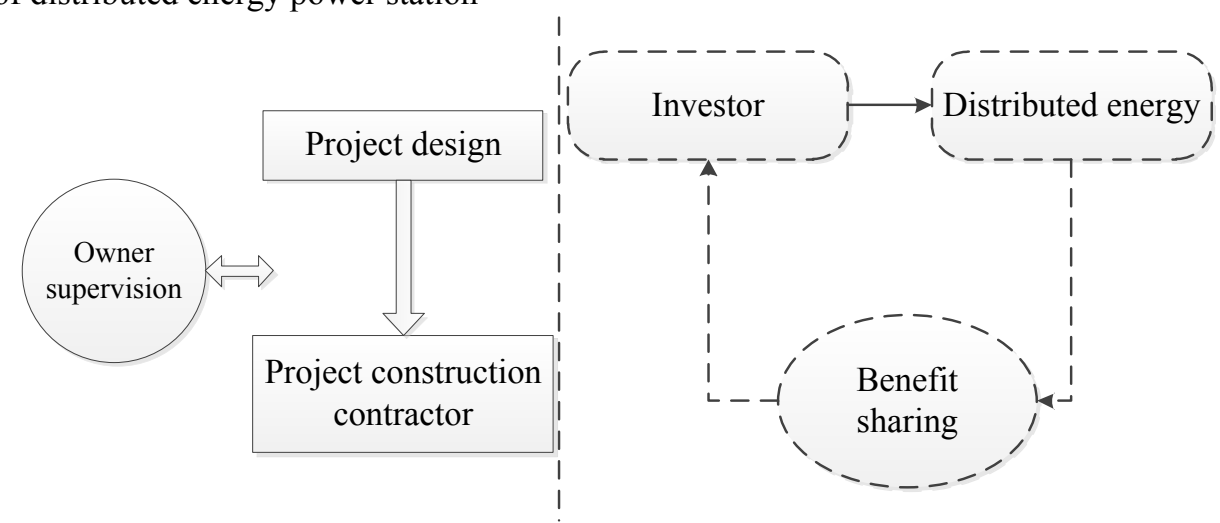

Figure 7 Distributed energy DB construction model

The DB model can coordinate investors and project contractors, and reduce the cost of distributed energy projects and shortens the project time. How to control the quality of project design is the key issue of DB model. Strict laws and regulations should be established to control the quality of construction and reduce the risks of contractors and owners.

The distributed energy engineering model also includes DBB (Design-Bid-Build) and the CM (Construction Management) model. The DBB model manages the whole process of the distributed energy project, which is controlled by the investor to the feasibility and design of the project, which can reduce the risk and the cost of the project investment. The CM model decomposes the project into a single project. A centralized management model is adopted to realize the full combination of the project design and the construction, which will shorten the construction cycle of the project.

\section{Conclusion}

In order to speed up the construction of distributed energy stations, the following measures should be taken. (1) to define the definition and standards of distributed energy in China; (2) to formulate distributed energy planning; (3) to formulate an incentive policy for distributed energy; (4) to formulate distributed technical standards. Smart grid is a revolution that combines IT industry with energy industry. It is an important way to solve the large scale grid connection of distributed power supply, by optimizing and analyzing the energy use data between users through the terminal sensor. Compared with other energy sources, the residual heat generated by distributed natural gas power generation can be fully utilized and the overall efficiency is high.

With the construction of distributed energy, it will also promote the development of power demand side management. The implementation of demand side manage- 
ment can promote the comprehensive optimization of various energy sources, and can provide the peak time reserve capacity.

\section{Acknowledgments}

This research was financially supported by State Grid Science and Technology Project (SGSXJY00PSJS1800003). The authors declare no conflict of interest.

\section{References}

1. PATHOMTH A T, CHIRADE J A, Ramakumar R. An approach to quantify the technical benefits of distributed generation.IEEE Transactions on Energy Conversion, 2004, 19(4):764-783.

2. Atzeni I, Ordonez L G, Scutari G, et al. Non cooperative arid Cooperative Optimization of Distributed Energy Generation and Storage in the Demand Side of the Smart Grid. Signal Processing IEEE Transactions on, 2013, 61(10):2454-2472.

3. Alarcon Rodriguez A, Haesen E, Ault G, et a1. Mufti objective planning framework for stochastic and controllable distributed energy resources. Iet Renewable Power Generation, 2009, 3(2):227-238.

4. Carpinelli G, Celli G, Mocci S, et al. Optimal Integration of Distributed Energy Storage Devices in Smart Grids.IEEE Transactions on Smart Grid, 2013, 4(2):985-995.

5. Pedrasa M A A, Spooner T D, Macgill I F. Coordinated Scheduling of Residential Distributed Energy Resources to Optimize Smart Home Energy Services. IEEE Transactions on Smart Grid, 2010, 1(2):134143.

6. Huang Jiayi, Jiang Chuanwen, Xu Rong. A review on distributed energy resources and Micro Grid. Renewable\& Sustainable Energy Reviews, 2008, 12(9):2472-2483.

7. Driesen J, Katiraei F. Design for distributed energy resources. Power \&Energy Magazine IEEE, 2008, 6(3):30-40.

8. Akorede M F, Hizam H, Pouresmaeil E. Distributed energy resources and benefits to the environment. Renewable\& Sustainable Energy Reviews, 2010, 14(2):724-734.

9. Akorede M F, Hizam H, Pouresmaeil E. Distributed energy resources and benefits to the environment. Renewable \& Sustainable Energy Reviews, 2010, 14(2):724-734.

10. Ren H, Gao W. A MILP modell for integrated plan and evaluation of distributed energy systems. Applied Energy, 2010, 87(3):1001-1014.

11. Yazdani D, Bakhshai A, Joos G, et al. A Nonlinear Adaptive Synchronization Technique for GridConnected Distributed Energy Sources. Power Electronics IEEE Transactions on, 2008, 23(4):21812186.
12. Chamam A, Pierre S. A distributed energy-efficient clustering protocol for wireless sensor networks. Computers \& Electrical Engineering, 2010, 36(2)303-312.

13. Wang X, Ma J, Wang S, et al. Distributed Energy Optimization for Target Tracking in Wireless Sensor Networks. Mobile Computing IEEE Transactions on, 2010, 9(1):73-86.

14. Alarcon Rodriguez A, Haesen E, Ault G, et al. Mufti-objective planning framework for stochastic and controllable distributed energy resources. Iet Renewable Power Generation, 2009, 3(2):227-238.

15. Contreras J, Losi A, Russo M, et al. Simulation and Evaluation of Optimization Problem Solutions in Distributed Energy Management Systems. Power Systems IEEE Transactions on, 2001, 17(11):57-57.

16. Zhang L, Gari N, Hmurcik L V. Energy management in a micro grid with distributed energy resources[J].Energy Conversion \&Management, 2014, 78(1):297-305.

17. Saha AK, Chowdhury S, Chowdhury S P, et al. Modelling and Performance Analysis of a Micro turbine as a Distributed Energy Resource. IEEE Transactions on Energy Conversion, 2009, 24(2)529-538.

18. Maribu K M, Firestorie R M, Marnay C, et al. Distributed energy resources market diffusion model. Energy Policy, 2007, 35(9) 4471-4484. 